Anno 34, 2019 / Fascicolo 1 / p. 140-142 - www.rivista-incontri.nl - http://doi.org/10.18352/incontri.10294 (C) The author(s) - Content is licensed under a Creative Commons Attribution 3.0 Unported License Publisher: Werkgroep Italië Studies, supported by Utrecht University Library Open Access Journals

\title{
The doctrine of the mean \\ Conversation in courtesy manuals from early modernity to the present
}

Review of: Giovanna Alfonzetti, 'Mi Iasci dire'. La conversazione nei galatei, Roma, Bulzoni, 2016, 250 p., ISBN: 9788868970628, € 21,00.

\section{Allegra Baggio Corradi}

Language is flexible and changing because it is as alive as man's attempt to establish a coherence between words and the world. The means through which language is tended, theorised and trained are important to understand how speakers think, act and interact, in reality as much as in fiction, at a given moment and in a particular context. The tacit and avowed rules of language prescribe not only that conversation be held in accordance to specific canons, but also that particular demeanours be adopted under certain circumstances in order to achieve specific aims. Linguistic etiquette and politeness are therefore inextricably embedded within political, literary and anthropological discourses, oscillating between nature and artifice. Scientific approaches to the study of linguistic etiquette, usually referred to as "second order politeness", are integrally bound to and dependent on the speakers' common sense perception of etiquette or "first order politeness". It is also true, however, that the discursive manifestation of politeness from the part of fictional speakers can emerge from art rather than from life, that is, from the mind of an author or theoretician rather than from living individuals. In the latter case, a study of the strategies adopted in a written conversation piece allows the contemporary reader to penetrate the mechanics of (un)politeness by assessing the continuities and disruptions between its own time and any past.

Giovanna Alfonzetti's 'Mi lasci dire'. La conversazione nei galatei undertakes precisely this task. The author endorses the view that politeness is a prototypically cooperative communicative behaviour whose aims are realised through a series of faceenhancing actions. She analyses these actions - turn-alternation, non-verbal communication, courteous listening, choice of code, linguistic competence and conversation topic - through the lens of linguistic pragmatics, devoting a chapter to each and every one of them. Alfonzetti moves from what she considers to be the prototype of courtesy books, Giovanni della Casa's Galateo (1558), and then compares this with a large number of etiquette manuals dating from the early modern period (Baldassare Castiglione's Cortegiano (1528)); pre- and post-unification Italy (Melchiorre Gioia's Nuovo Galateo (1802), Giacinto Gallenga's Codice delle persone oneste e civili: ossia galateo per ogni classe di cittadini (1871), Costantino Rodella's Enrichetto, ossia il galateo del fanciullo (1873) and Marina, ossia il galateo della fanciulla (1873), and Matteo Gatta's Galateo ad uso dei giovanetti (1877)); Fascism (Castellino's Libro della cortesia. Nuovo galateo per i giovinetti (1920), Pierazzi's Per 
essere felici. II libro della cortesia (1922), Brelich Dall'Asta's II successo della vita. Galateo moderno (1931)); and the post-war period (Piccini's II tesoro (1951), Mosca's II nuovo Galateo. Come ci si doveva comportare ieri, come ci si deve comportare oggi (1980), and Barbara Ronchi della Rocca's Si fa non si fa. Le regole del galateo 2.0 (2013)).

Rather cunningly, Alfonzetti starts her analysis of polite conversation from the study of silence. The author considers the unavowed rules of conversational interruption in relation to their appropriateness and inadequacy in specific contexts and enhances the irreconcilability of second order politeness in this regard. In the second chapter, Alfonzetti assesses the socio-symbolic implications of prosodic and kinesic actions, that is, non-verbal forms of communication, such as facial expression, posture, gaze and invasion of personal space. In this respect, the author argues that the most substantial change from humanist to post-unitarian manuals is the progressively stronger emphasis placed on emotion and empathy. In the third chapter, Alfonzetti studies the role of the audience, focusing, in particular, on the growing importance placed on the listener from early modernity to the present times. In the fourth chapter, the author discusses the choice of linguistic code, with a particular emphasis on the appropriate use of dialects, foreign languages and other "in-group identity markers". In the fifth chapter, Alfonzetti addresses the issue of linguistic competence through the analysis of technicalities such as proper pronunciation, hyperarticulation, hypoarticulation, stress, politically-correct terminologies, jargon, neologisms, malapropisms and plastisms. In the sixth chapter, Alfonzetti amply discusses the choice of conversation topics. In this regard, she emphasises the importance for a speaker to avoid causing nuisance to the listener's disposition (appetito), imagination (immaginazione) and senses (sensi) and his ability to claim common ground by avoiding self-referential, sad, blasphemous or potentially controversial topics such as politics and religion.

In her sophisticated conclusion, Alfonzetti provides a thorough recapitulation of the previous chapters, convincingly arguing that despite the discrepancies between the individual texts analysed, all authors express their desire to write an updated conduct manual suitable for their times although they, either consciously or inadvertedly, reiterate the principles exposed by their predecessors. The major changes from humanist to modern conversation etiquette consist in the shifting views on gender; in the progressive transformation of courtesy books 'from manuals of proper living to manuals of surviving, in which the attention to the presentation and realisation of the self is ever greater' (p. 33); in the psychologisation of the listener at the turn of the twentieth-century together with the development of psychoanalysis; and in the evolving notion of "civilisation". The most important continuity Alfonzetti highlights is the doctrine of the mean (giusto mezzo), a claim to the avoidance of extremes in conversation, from not speaking too much about oneself to speaking too much all together.

Overall, although Alfonzetti, by no means slavishly, follows Andreas Jucker and Irma Taavitsainen's historical pragmatics, borrowing much also from Annick Paternoster's and Richard Watts's studies on the pragmatics of politeness, she is able to contribute significantly to scholarship through her sound, wide-ranging and cautious study. Her diachronic approach to the investigation of politeness is convincing and wisely articulated, certainly making the case for non-normative (un)politeness better than a chronological approach would be able to do. Her criticisms towards recent conduct manuals are justified and very elegantly articulated, a perfect example of polite misura, which counters the acrimony of much contemporary scholarship. For this, Alfonzetti should be praised and politely thanked. 
Allegra Baggio Corradi

The Warburg Institute

Woburn Square

WC1H OAB

London (UK)

allegra.baggiocorradi@postgras.sas.ac.uk 